\title{
Factors Influencing High Unemployment in Tajikistan
}

\author{
Nasridini Asliddin ${ }^{1}$, Behrooz Gharleghi ${ }^{1,2}$ \\ ${ }^{1}$ Faculty of Business and Management, Asia Pacific University of Technology and Innovation, Kuala Lumpur, Malaysia \\ ${ }^{2}$ Centre of Socio-Economics of Ageing (CSEA), Asia Pacific University of Technology and Innovation, Kuala Lumpur, \\ Malaysia \\ Correspondence: Behrooz Gharleghi, Faculty of Business and Management, Asia Pacific University of Technology and \\ Innovation, TPM, 57000, Bukit Jail, Kuala Lumpur, Malaysia. Tel: +60 196153515.
}

Received: July 9, 2015

Accepted: July 20, 2015

Available online: September 6, 2015

doi:10.11114/ijsss.v3i6.938

URL: http://dx.doi.org/10.11114/ijsss.v3i6.938

\begin{abstract}
The main aim of this paper is to identify the major determinants of unemployment in Tajikistan. As a result, three independent variables are chosen to be tested which are, lack of education, lack of skills, and low wages. The scope of the study is the population of Tajikistan and we followed the random sampling technique to collect the data. The data hence collected during April to May 2015 and a total of 390 usable questionnaires obtained. The regression results show that there is a positive and significant relationship between the lack of education and low wages with unemployment in the country. But there found no relationship between lack of skills and unemployment.
\end{abstract}

Keywords; lack of education, lack of skills, and low wages, unemployment

JEL Codes: E24, F22, O15

\section{Introduction}

In the middle of the $20^{\text {th }}$ century Soviet Union started to face a big problem which is unemployment. This was one of the main reason why Soviet Union collapsed. After Soviet Union collapsed Tajikistan has got it is independence in 9 of September 1991. Since, Tajikistan was part of the Soviet Union before, it was facing the same challenges with unemployment. From 1992 until 1995 there was Civil War which people divided in to two parts, one for them wanted to have the Communist country while another part wanted Islamic country. During this civil war citizens face another problem which is scarcity of the food. In Tajikistan their main food is bread, therefore, this scarcity leads people to eat bread with husk and corn and some other staff. This was very tragic moment for each citizens of Tajikistan (Schweizer, 1994).

Started from Civil War in Tajikistan there was problem with high unemployment. Most of the scientists and knowledgeable people left Tajikistan to other countries as Russia and US. The Current situation shows that almost 2 million citizens of Tajikistan migrated to Russia in order to find some jobs (Human Rights Watch, 2011).

Tajikistan also facing a big problem which is unemployment of the citizens where it causes migration of civilians. The Index Economy Freedom portrays that unemployment rate in 2014 was 2.5\%. According to Russian Migration Service about 2 millions of Tajik citizens migrate to Russia to find job. From this most of them are under 18- 29 ages while only few of them are 30 and above (Salimov, 2014). During these ages they supposed to gain knowledge or skills which would be helpful for them but their life force them to find work. In addition to this, poverty is very high in Tajikistan, according to research $86 \%$ of the citizens of Tajikistan live below poverty which means it is really high. Besides that, in Khatlon Region there has been made a research where mentioned that this region is agriculture part of Tajikistan and only $3 \%$ has been employed in agriculture which is very less. In this oblast about 2.7 million people live and out of 2.7 Million only 3\% has been employed. In total in this region about 30\% people has been unemployed which is very high (Bakanova and Carneiro, 2014). If in one region the number of unemployment tis about $30 \%$ then in other regions also might be high as well. Thus, unemployment in Tajikistan is very big problem which people migrated to Russia and find job there. Therefore, the researcher focus on the factors which is effecting the unemployment to be high in Tajikistan.

In Tajikistan unemployment day by day rising. Most of the citizens are lack of knowledge or skills. The research has been done in 2011 and it is show that about 98\% of Tajik citizens who work in Russia are lack of skill (Lemon, 2011). Besides that, there seems to be some feminism as well which increase the number of unemployment in Tajikistan. This 
is because, the research depicts that, in Tajikistan men have 30\%-40\% opportunity to find job than female. And, elderly would be employed faster than young due to having more experience. Based on this research, men are $27 \%$ has been self-employed while women only $12.6 \%$. As the result, it shows that there are feminism in Tajikistan which leads to increase unemployment over there (Shemyakina, 2014). Another main issue is lack of knowledge which causes unemployment. Migration of the citizens help the economy of Tajikistan to boost little bit. The recent research which has been done by World Bank show that the GDP of Tajikistan in 2012 was US 6.9 billion. From this amount 3.3 billion will come from Migrants who are in Russia (Salimov, 2014). From this we can estimate that if there are no migrants of citizens Tajikistan's GDP would go down and the economy will be very low. Tajikistan depends too much to its migrants in order to develop economy.

The main objective of this research is to identify whether there is any relationship between independent variables of "lack of education", "lack of skills", and "low wages" and the dependent variable of "unemployment" in the case of Tajikistan.

There are several reasons which motivate the researcher to do this research about factors of unemployment in Tajikistan. Firstly, researcher see this as one of the major problem of Tajikistan due to many people suffer under this and migrate specifically to Russia and other countries. Secondly, the researcher want to contribute through this way at least some ideas on how to overcome unemployment in Tajikistan.

The significance of this research is to understanding how is the situation of unemployment in Tajikistan, reasons and causes of unemployment in Tajikistan and how to solve it by giving some recommendation. In addition to this, as we know employment is the key to develop the economy of the country and satisfy citizens. Thus, the researcher going to look for suggestion in order to increase employment in Tajikistan. Furthermore, this research will give more information about Tajikistan's life and unemployment factors so that government can get some ideas to reduce unemployment rates.

The remainder of the paper is organized as follows. Section two outlines the extant literature, while Section 3 introduces the basic theory underlying the methodology. Section 4 describes the data, and our empirical findings are presented in this section. Section 5 concludes the paper.

\section{Literature Review}

\subsection{Unemployment}

"Unemployment" means people who are able to work but there is no job or cannot find job for them for some reasons. Unemployment rate is an important economic indicator which can help people to identify the weaknesses or the power of certain countries' economy. Martin (2012) examine unemployment in Namibia which is half of population is unemployed. According to the research Namibia Labor Force Survey in 2008, 51.2\% of citizens are unemployed which is Namibia in the list of high unemployment country in the world. The researcher used Classical Labor Surplus Model where it separate labor market into two parts: modern and traditional. It is used secondary data with qualitative approach. And, the respondents' ages are 15 and above due to people start working from 15 years old. It is taken the data from 1997-2008. The results shows that in 2008 unemployment increased by $18.4 \%$. Rural area unemployed people was higher than urban which is urban $36.4 \%$ while rural $64.9 \%$. As a result it its shows that it is achievable to employed civilians due to now it is improving.

Mossakowski (2009) investigates on the influence of past unemployment as an indicators for depression on young males and females in United States. The researcher use secondary data from National Longitudinal Survey of youth (NLSY) based on 1979 to 1994 surveys. The research conducted as quantitative research. During 1979 the respondent were between 14 to 22 years, and about 12686 individuals responded individually as quantitative research which is interview. In 1994 the data has been collected based on the age of 29 to 37 years old folks. The result shows that 1.5\% was unemployed as a sample and $17 \%$ was looking for job and $78 \%$ was employed. The regression analysis depicts there is less significant analysis. In 1994 result portrays significant effect of unemployment which is about 0.08 to 0.13 .

\subsection{Lack of Education}

"Lack of Education" can be defined as society will not get enough knowledge or some part of the society does not get knowledge which means illiterate. The research shows that 759 million people are does not have basic knowledge and 67 million of children has limited access to go to the schools due to they live under poverty (interculturas, 2014).

Isakova and Nazarbekova (2011) analyzing low quality of education to lead for high unemployment in Bishkek. They use cluster sampling for the research. It has been surveyed on 400 respondents which chosen randomly. The researchers using qualitative and quantitative together which the interview has been taken from suburbs and other data has been taken quantitatively. The researcher use SPSS in order to find the findings. The result of survey depict that, $82.90 \%$ of the parents say it is difficult to provide education to their children. It means the quality education is low and causes unemployment. As the result, 23\% parent have technical knowledge, $6.3 \%$ did not completed higher education and $48 \%$ 
finish secondary school. The researcher claims that, the data collected above shows that parent want their children to be educated as long as they have enough money for their studies.

Qayyum (2007), checked the reasons for youth unemployment in Pakistan. The research use secondary data based on Labor Force Survey 2003-2006. It is shows that one of the main reason for unemployment there is lack of education. The data has been collected from 14515 household where 1151 found to be unemployed and 13364 has been employed. Out of this research, people who has primary education has less opportunity to find job which is about $2.3 \%$. For people who are studied in colleges or universities have the probability to find job increased to $20.1 \%$. Therefore, in Pakistan the people who have high qualification, can find job but for lack educated people is based on opportunities.

Based on the above literature, following hypothesis can be made:

H1: There is a relationship between Lack of education and unemployment in Tajikistan.

\subsection{Lack of Skills}

"Lack of skill" it is a person who has less ability to do something or someone who are not confidence whether they are doing correct or no. According to Joerres (2012), the current employers have a big problem to find talented workers which they need but, due to gap of skills it is very hard for them to find it. The researcher claims that about $50 \%$ of employers in US are having difficulty to find employees and $40 \%$ says it is difficult to find skilled employees. Another researcher Peacock (2011) claims that the survey has been done on 626 employers by Chartered Institute of Personnel and Development. It is result depicts that most of employers complaint about hiring employees but there was big problem due to employees do not like to take risk and have less skills.

Vickery (1999) to investigate whether unemployment in Australia is due to unskilled and why people with skills enjoy their employment. The data has been collected from Transition from Education to Work. It is also show the higher unemployment rate. It is used theoretical frame work as labor demand curve and wage setting curve. The survey has been done from 2311 individuals randomly. The result shows that people who is with skilled increase their employment to $2.8 \%$ and for unskilled it is only increase by $1.9 \%$. It is also shows that $16.8 \%$ of graduate has been employed while only $8.9 \%$ does not have job.

Levine (2013) check why unemployment is high as much as vacancies of jobs and whether it is due to lack of skills or no. the data has been taken from US, Wisconsin and Milwaukee. The research use quantitative data which is secondary data. Manufacturing institute shows in 2011 survey has been done among 1123 people which $67 \%$ of them said they are lack of skills. The ratio of unemployed is 12.6. On the other hand, the researcher compares between another researches which has been done in 2009 by Bureau of Labor Statistics. It is claims that there is no correlation between 2007 and 2009 unemployment and it does not have any relationship with unqualified workers which is talk about skills and its gaps. Based on Wisconsin, there is high relationship between skills and unemployment. Thus, from the above literature review, the researcher can assume the following hypothesis:

H2: There is a relationship between Lack of skill and unemployment in Tajikistan.

\subsection{Low Wages}

"Low Wage"- some researcher has defined it as people who has been employed by low wages hourly which is in the list of low wage distribution. Some researcher as Gladden and Taber (1999) agree on this point by saying low wage workers are those who are below $20^{\text {th }}$ Percentile of the wage distribution. Another researcher define low wage workers as who get low income which is not enough for their family needs (Schochet and Rangarajan, 2004).

Mavromaras, Sloane and Wei (2003) examine the effects of unemployment, low wage and lack skills under-utilization in Australia. The researcher collected the data as secondary data of 10 years based on Household, Income and Labor Dynamic in Australia (HILDA). The survey has been taken from both gender as sample. The respondent ages was male 16-64 while female ages were 16-59. The researcher use Qualitative types based on observation about 6000 people of sample size ant it is only base on Australia. The result portrays, the lowest earning per hour is AU\$ 11.33. Furthermore, AU\$ 16.67 per hour considered low pay as mentioned above. The result depicts that, in general in Australia there were about $42.8 \%$ unemployed which is mostly due to wages are very low. They concluded that, both males and females low wage workers highly significant to be unemployed rather than high wage workers.

Bhalla and Das (2005) analyzed unemployment and wage growth in India for the last 25 years. Based on the research it shows that the wages of people in 1999 decline to $1.9 \%$. The research used secondary data from National Sample Survey from 120,000 households by using qualitative data which there was weekly survey as well by NSSO. National Sample Survey's data shows that agricultures' wage increase by $2.8 \%$. The finding depicts $1.5 \%$ increase on unemployment rates. Graduate people who effected by low wage was $5 \%$. Consequently, from the above literature review, the researcher came out by the following hypothesis: 
H3: There is a relationship between low wage and unemployment in Tajikistan.

Most of the previous studies did not do for the whole of population of the country which means the data might be not so reliable. Moreover, other researchers did not test through regression or correlation which can shows the relationship of objectives and hypothesis. These two weaknesses can be seen in majority of the research which is not clear. For this research which has been done in Tajikistan, the data has been collected based on size of population which might portrays the real data and gives more coherent result. Thus, other research would be great if they consider their data collection based on population size.

\section{The Methodology and Model}

The researcher considered the primary data collection from April to May 2015 using quantitative technique research. The sample size is 390 individuals due to size of population of Tajikistan (8,000,000 people) using Krejcie and Morgan (1970). The questionnaires will be taken from Tajikistan's citizens who are 18 and above. The data was collected using random sampling techniques. The questionnaires has been designed based on the four variables which are independent and dependent variables. Cronbach reliability test, Pearson correlation test, ANOVA test as well as regression analysis are implemented on the data collected to achieve the objectives of the research which are the identification of the relationship among the variables considered. The model that is going to be investigated is as follow:

Unemployment $=\beta_{0}+\beta_{1}$ Lack of Education $+\beta_{2}$ lack of skills $+\beta_{3}$ low wages

\section{Empirical Results}

The data has been collected from both gender male and female and the result shows that out of 390 respondents, $64.6 \%$ was male and $35.4 \%$ was female respondent.

\subsection{Descriptive Statistics}

Table 1 shows the descriptive statistics of the four variables under consideration.

Table 1. Descriptive Statistics

\begin{tabular}{llllll}
\hline Variables & N & Minimum & Maximum & Mean & Std. Deviation \\
\hline Unemployment & 390 & 9.00 & 20.00 & 17.1846 & 1.95101 \\
Lack of Skill & 390 & 12.00 & 30.00 & 25.6590 & 3.02502 \\
Low Wage & 390 & 12.00 & 30.00 & 26.4410 & 2.31356 \\
Lack of Education & 390 & 9.00 & 30.00 & 25.3744 & 3.06458 \\
Valid N (listwise) & 390 & & & &
\end{tabular}

The data has been collected for each variable therefore, each variables have different means and standard deviation. The independent variable which is unemployment has certain mean and standard deviation where it has been based on respondent response.

\subsection{Reliability Test}

The reliability test has been conducted by the researcher in order to analyze the degree of goodness and the balance of variables. Table 2 shows the performance of Cronbach's Alpha with internal consistency, while table 3 shows the result of this study;

Table 2 Performance of Cronbach's Alpha

\begin{tabular}{ll}
\hline Cronbach's alpha & Internal consistency \\
\hline$\alpha \geq 0.8$ & Excellent \\
$0.7 \leq \alpha<0.8$ & Good \\
$0.6 \leq \alpha<0.7$ & Acceptable \\
$0.5 \leq \alpha<0.6$ & Questionable \\
$\alpha<0.5$ & Unacceptable \\
\hline
\end{tabular}

Table 3 Reliability Test

\begin{tabular}{ll}
\hline Cronbach's Alpha & No of Variables \\
\hline .666 & 4 \\
\hline Based
\end{tabular}

Based on the data which has been collected, the Cronbach alpha obtained as .666 which can be considered as acceptable. The number of items which is 4 represent all the variable which is independent and dependent variables. From this it 
can be say that our research is reliable and acceptable for future use and analysis.

Pearson Correlation

\subsection{Correlation Analysis}

Pearson's Correlation Analysis it is investigation technique which determine the relationship two or more variables by coefficient which is known as (r) and it is check the significant relationship between variables. The Pearson Correlation portrays the relationship of variables by three possible answers which are; negative, positive and no relationship. If the result of Pearson Correlation shows as 1 or nearby 1 means there is significant relationship between tested variables. However, if the result depicts -1 means it is negative relationship and lastly if it shows the result as 0 means there is no relationship between these variables. Table 4 shows the critical values for correlation test while table 5 shows the result of correlation analysis;

Table 4. Pearson correlation critical values

\begin{tabular}{cccccc}
\hline Value of the correlation coefficient & 1 & $0.7-0.9$ & $0.4-0.6$ & $0.1-0.3$ & 0 \\
\hline Strength of correlation & Perfect & Strong & Moderate & Week & zero \\
\hline
\end{tabular}

Table 5. Pearson Correlation Results

\begin{tabular}{lllll}
\hline Dependent variable & & Lack of skills & $\begin{array}{l}\text { Lack } \\
\text { Education }\end{array}$ & of \\
& & & $.219^{* *}$ & $.296^{* *}$ \\
Unemployment & Pearson Correlation & 0.189 & .000 & .000 \\
& Sig. (2-tailed) & 0.000 & 390 & 390 \\
\hline
\end{tabular}

Base on the above table which portrays the correlation of unemployment and lack of skills, lack of education, low wages, it can be seen that correlations are positive, significant but weak. Therefore, the researcher based on result claims that independent variables weakly affect the unemployment. But further to this test, regression analysis is required to test the developed hypotheses and also find the relationship among the variables once they are all in consideration.

\subsection{Regression Analysis}

The weakness of Pearson correlation is that it is usually considers a pair of two variables only to check the correlation and it does not contain significant information as regression does. Following tables represents the result of regression analysis in order.

Table 6. R Square of the Model

\begin{tabular}{llll}
\hline $\mathrm{R}$ & $\mathrm{R}$ Square & Adjusted R Square & Std. Error of the Estimate \\
\hline .894 & .801 & .789 & 1.85706 \\
\hline
\end{tabular}

Predictors: (Constant), Lack of Education, Low Wage, Lack of Skill

Model summary depicts that R Square is 0.801 which means there is significant effects of all independent variables toward unemployment.

Table 7. ANOVA Test

\begin{tabular}{llllll}
\hline & Sum of Squares & d.f & Mean Square & F-stat & Sig. \\
\hline Regression & 149.526 & 3 & 49.842 & 14.453 & $.000^{\mathrm{a}}$ \\
Residual & 1331.182 & 386 & 3.449 & & \\
Total & 1480.708 & 389 & & & \\
\hline
\end{tabular}

Dependent Variable: Unemployment

Based on the research data collection the above ANOVA table portrays the level of significance relationship of all the hypothesis towards unemployment in Tajikistan. This is statistically significant as the value of $\mathrm{P}$ is less than value of $0.05(\mathrm{P}<0.05)$. Furthermore, there is a significant difference between the mean of the variables. 
Table 8. Regression Coefficients

\begin{tabular}{llllll}
\hline & \multicolumn{2}{l}{$\begin{array}{l}\text { Unstandardized } \\
\text { Coefficients }\end{array}$} & & \multicolumn{2}{l}{$\begin{array}{l}\text { Standardized } \\
\text { Coefficients }\end{array}$} \\
\cline { 2 - 5 } & B & Std. Error & Beta & t-stat & sig \\
\hline (Constant) & 9.520 & 1.176 & & 8.095 & .000 \\
Lack of Skill & .026 & .037 & .040 & .704 & .480 \\
Low Wage & .199 & .046 & .236 & 4.299 & .000 \\
Lack of Education & .068 & .036 & .107 & 1.970 & .050 \\
\hline
\end{tabular}

Dependent Variable: Unemployment

Based on the above coefficient table it portrays that there are significant relationship between low wage and lack of education towards unemployment as analyzed by SSPS. The $\mathrm{p}$ value for these two variables are less/equal to 0.050 and therefore they found to be significant in the model. Based on the regression results, following table shows the result of hypotheses testing;

Table 9. Hypotheses Testing

\begin{tabular}{|c|c|c|c|}
\hline Hypothesis & Statements & Findings & Results \\
\hline H1 & $\begin{array}{l}\text { There is a relationship between Lack } \\
\text { of education and unemployment in } \\
\text { Tajikistan. }\end{array}$ & $\begin{array}{l}\mathrm{P}=0.05 \\
\text { Since } \\
\mathrm{P}=0.05\end{array}$ & $\begin{array}{l}\text { This hypothesis is } \\
\text { accepted }\end{array}$ \\
\hline $\mathrm{H} 2$ & $\begin{array}{l}\text { There is a relationship between Lack } \\
\text { of skill and unemployment in } \\
\text { Tajikistan. }\end{array}$ & $\begin{array}{l}\mathrm{R}=0.418 \\
\text { since } \\
\mathrm{P}>0.05\end{array}$ & $\begin{array}{l}\text { This hypothesis is } \\
\text { rejected }\end{array}$ \\
\hline H3 & $\begin{array}{l}\text { There is a relationship between low } \\
\text { wage and unemployment in } \\
\text { Tajikistan }\end{array}$ & $\begin{array}{l}\mathrm{R}=0.00 \\
\text { since } \\
\mathrm{P}<0.05\end{array}$ & $\begin{array}{l}\text { This hypothesis is } \\
\text { accepted }\end{array}$ \\
\hline
\end{tabular}

\section{Discussion}

\subsection{Lack of education}

We found that lack of education is significant towards unemployment. A research has been done by Srivastav and Dubey (2010) portrays there are relationship between unemployment and lack of education due to it is regression is significant as $\mathrm{P}=0.046$. Besides that, unemployment in Turkey also has been affected due to lack of education. It is because, 18\% school graduates are unemployed Kabaklari, Hazeler and Bulus (2011). Thus, the researches would shows different based on the countries. Means that in Tajikistan education is one of the main factors for unemployment to be high.

\subsection{Lack of skills}

Based on the literature, several estimation has been done by other researchers as Wallis (2002) did the research on unemployment in UK and one of it is IVs was Lack of skills which the result portrays that regression analysis is highly significant. It is because it shows that about $27 \%$ of people was lack of skills and that is why they could not manage to find job. Another, research has been done in US by Levine (2013) and he claim and he claimed there is high relationship between unemployment and lack of skills. However, this new research has been done and the researcher came out with different findings which is there is no relationship between lack of skills and unemployment in Tajikistan.

\subsection{Low wages}

The researcher claims that based on the results of these three IVs in this research the factors which mostly affect Tajik citizens to be unemployed are low wage and lack of education because based on Pearson's correlation these two factors are the strongest factors than lack of skills yet it also have the positive relationship between DV. Moreover, based on the literature, there are several results has been came out. Moghadam and Rijckeghem has done research on 1995 which shows there are significant relationship between low wage and unemployment in Belgium. Another research has been done in Germany by Mosthaf and Schnabel (2009) and it shows no relationship between unemployment and low wage. Our findings also support their studies as there is a significant relationship between low 
wages towards unemployment.

\section{Conclusion}

The main aim of this paper was to identify whether lack of education, lack of skills, and low wages contributes to the unemployment in Tajikistan. The paper is done based on the quantitative research and created questionnaires to collect the data. The collection process occurred in Tajikistan as the scope of the study. Moreover, the researcher collected data from 390 individuals randomly where the age of people was from 18 and above. Furthermore, after collecting the data, the researcher has done several tests in order to get the results whether particular variables can affect unemployment in Tajikistan. Reliability tests, Pearson correlation test, ANOVA, and Regression Analysis. Based on the regression results, there found to be a significant relationship between low wage and lack of education towards unemployment in Tajikistan. Nonetheless, lack of skills has less significant relationship to unemployment in Tajikistan. Therefore, the main reasons for unemployment to be high in Tajikistan is lack of education of most citizens and low wage payment by the employers.

\subsection{Practical Implication}

The findings of this research provides some insight to the reasons of why unemployment is high in Tajikistan. As a result, we found that lack of education and low wages contribute significantly to this issue. Therefore it is the government responsibility to provide more free education for the citizens probably in higher level to educate them properly in order to be ready for job market. In the other side, minimum wage scheme should be revised and adjust accordingly in order to discourage people migrate outside the country.

\subsection{Limitations}

The main limitation of this study is that the respondents were not from government sector that they may had a better idea of the unemployment issue in the country.

\section{References}

Bahalla, S., \& Das, T. (2005). Unemployment \& wages in India: Ideology, reforms, evidence, Oxus Research and Investments, 1-62.

Bakanova, M., \& Carneiro, F. (2014). 'Tajikistan: Reinvigorating growth in Khatlon Oblast', Public Disclosure Authorized, 70, 1-4.

Gladden, T., \& Taber, C. (1999). Wage progression among less-skilled workers. Institute for Policy Research, Northwestern University.

Human Rights Watch. (2011). 'Reported Roundup of Tajik Migrants', 15 November. Available at: http://www.hrw.org/news/2011/11/15/russia-reported-roundup-tajik-migrants. Accessed on: 20 November 2014.

Interculturas, (2014). 'Why is the lack of education a priority program?' available at: http://www.entreculturas.org/conocenos/english/lack_of_education_a_priority_problem.

Isakova, K., \& Nazarbekova, R. (2011) 'Lack of education today- Unemployment tomorrow', international and comparative politics, 1-21.

Joerres, J. (2012). 'lack of skills is serious problem for companies', The New Your Times, 10 July. Available at: http://www.nytimes.com/roomfordebate/2012/07/09/does-a-skills-gap-contribute-to-unemployment/lack-of-skills-i s-a-serious-problem-for-companies accessed on 20 January 2015.

Kabaklarli, E., Hazeler, P., \& Bulus, A. (2011) 'Economic determination of Turkish youth unemployment problem: co-integration analysis', International Conference on Applied Economics, 267-272

Krejcie, R. V., \& Morgan, D. W. (1970). Determining sample size for research activities. Educ Psychol Meas., 30: 607-610.

Lemon, E. (2011) 'Russia: Central Asia labor migrants facing uncertain year', Euraasianet, 5 January [Online]. Available at: http://www.eurasianet.org/node/62664 Accessed on 5 May 2014

Levine, V. (2013). 'The skills gap and unemployment in Wisconsin', University of Wisconsin-Milwaukee. February, $1-55$.

Martin, S (2012) 'Unemployment in Namibia: Measurment problems, causes and politics', First Capital Working Paper Series, 1-66.

Mavromaras, K., Sloane, P., \& Wei, Z. (2013) 'The scarring effects of unemployment, low pay and skills under-utilization in Australia compared', IZA, 1-30. 
Moghadam, R., \& Rijckeghem, C. (1995) 'Unemployment hysteresis, wage determination, and labor market flexibility: The case of Belgium', IMF Staff Papers, 42(4), 882-893.

Mossakowski, K. (2009). 'The influence of past unemployment duration on symptoms of depression among young women and men in the United States', American Journal of Public Health, 9(10), 1826-1832.

Mosthaf, A., Schank, T., \& Schnabel, C (2009). 'Low wage Employment versus unemployment: which one provides better prospects for women', IZA. December, 1-28

Peacock, L. (2011). 'Lack of skills leaves employer struggling to fill vacancies', The Telegraph, 15 June. Available at: http://www.telegraph.co.uk/finance/jobs/8575852/Lack-of-skills-leaves-employers-struggling-to-fill-vacancies.htm 1 Accessed on 1 January 2015.

Qayyum, W. (2007). 'Causes of youth unemployment in Pakistan', The Pakistan Development Review, 46(4), 611-621.

Salimov, O. (2014). 'Tajikistan ratifies agreement with Russia on Tajik labor migrants', The Central Asia Caucasus analyst, 19 February. Available at:

http://www.cacianalyst.org/publications/field-reports/item/12914-tajikistan-ratifies-agreement-with-russia-on-tajiklabor-migrants.html

Schochet, P., \& Rangarajan, A. (2004). 'Characteristics of Low-Wage Workers and Their Labor Market Experiences: Evidence from the Mid- to Late 1990s', U.S. Department of Health and Human Services. Office of the Assistant Secretary for Planning and Evaluation, 1-250.

Schweizer, P. (1994). Victory: The Reagan administration's secret strategy that hastened the collapse of the Soviet Union. Atlantic Monthly Press.

Shemyakina, O. (2014). 'Labor market outcomes in post-conflict Tajikistan', Georgia Institute of Technology, 1-40.

Srivastav, N., \& Dubey, A. (2010). 'Unemployment in north-east India: some issues', North-Eastern Hill University, Shillong. 1-18.

Vickery, J. (1999). 'Unemployment and skills in Australia', Reserve Bank of Australia. December, 1-53.

Wallis, G. (2002). 'the effect of skill shortages on unemployment and real wage Growth: A simultaneous Equation Approach', Office for National Statistics, 1-59.

\section{(c) $)$ EY}

This work is licensed under a Creative Commons Attribution 3.0 License. 